Підсумовуючи вищезазначене, зауважимо, що розвивальне навчання математики здійснюється у формі навчально-математичної діяльності й передбачає нелінійну модель організації навчального процесу. Системотвірні компоненти цієї моделі представляються ситуацією успіху, проблемною ситуацією, цілепокладанням, дослідженням, змістовотеоретичним абстрагуванням та узагальненням, розв'язуванням типових задач, рефлексією процесу учіння, системністю математичних знань. Розроблений на цій основі розвивальнозадачний метод навчання математики забезпечує актуалізацію науково-теоретичного мислення, розв'язання проблеми походження теоретичних знань, водночас, репрезентує задачний підхід до формування навчально-математичної діяльності та розвитку математичних здібностей, уможливлює суб'єктну поведінку та створення зон найближчого математичного розвитку учнів. Науково-теоретичному обгрунтуванню концепції моделі навчально-математичної діяльності учнів будуть присвячені наші подальші роботи.

\title{
Література
}

1. Бобков В. В. Дифференцированный подход к обучению: психоинформационная точка зрения. Часть 1 / В. В. Бобков / [Электронный ресурс].- Режим доступа : http://zhurnal.ape.relarn.ru/articles/2006/041.pdf， 29. 06. 2006 p. 2. Богоявленская Д. Б. Психология творческих способностей : [уч. пособ. для студ. высш. учеб. заведений] / Д. Б. Богоявленская. - Москва : Академия, 2002. - 320 с. 3. Выготский Л. С. Педагогическая психология / Л. С. Выготский - Москва : Педагогика, 1991. - 480 с. 4. Гальперин П. Я. Формирование умственных действий и понятий / П. Я. Гальперин. Москва : МГУ, 1965. - 146 с. 5. Давыдов В. В. Виды обобщения в обучении (логикопсихологические проблемы построения учебных предметов) / В. В. Давыдов. - Москва : Педагогика, 1972. - 424 с. 6. Дусавицкий А. К. Развивающее образование: теория и практика. Статьи / А. К. Дусавицкий. - Харьков : ХНУ. - 2002. - 146 с. 7. Лернер И. Я. Дидактические основы методов обучения / И. Я. Лернер. - Москва : Педагогика, 1981. 186 с. 8. Семенець С. П. Методологія і теорія розвивального навчання математики : [монографія] / С. П. Семенець. - Житомир : Вид-во О. О. Овенок, 2015. - 236 с. 9. Семенець С. П. Системотвірне поняття та особливості змісту розвивального навчання математики / С. П. Семенець // Педагогіка вищої та середньої школи : [зб. наук. праць] / ДВНЗ «Криворізький національний університет». - Кривий Ріг, 2015. - Вип. 46. - С. 207-212. 10. Слепкань 3. И. Психолого-педагогические основы обучения математике / 3. И. Слепкань. - Київ : Рад. школа, 1983. - 192 с. 11. Сухомлинський В. О. Розмова 3 молодим директором школи / В. О. Сухомлинський // Вибрані твори : у 5 т. - Київ : Рад. шк., 1976. - Т. 1. - 544 с. 12. Талызина Н. Ф. Управление процессом усвоения знаний / Н. Ф. Талызина. - Москва : МГУ, 1975. - 343 с.

\section{АКТИВІЗАЦІЯ ТВОРЧОЇ ДІЯЛЬНОСТІ МОЛОДШИХ ШКОЛЯРІВ НА УРОКАХ МУЗИКИ}

Шарапова Т. А. Активізація творчої діяльності молодших школярів на уроках музики.

У статті розглядаються методи і прийоми роботи вчителя з удосконалення музичнотворчої діяльності учнів засобами імпровізації. Розглянуто імпровізацію як вид діяльності на уроках музики та іiі вплив на музичний розвиток молодших школярів. Обгрунтовано методику організації музичної імпровізаційної діяльності учнів молодшого шкільного віку та 
роль учителя в загальному музичному розвитку молодших школярів.

Ключові слова: імпровізація, основи імпровізації, методи імпровізації, імпровізаційна діяльність, імпровізаційні завдання.

Шарапова Т. А. Активизация творче ской деятельности младших школьников на уроках музыки.

В статье рассматриваются методы и приёмы работы учителя по усовершенствованию музыкально-творческой деятельности учеников средствами импровизации. Обращается внимание на импровизацию как вид деятельности на уроках музыки и её влияние на музыкальное развитие младших школьников. Обосновывается методика организации музыкальной импровизационной деятельности учеников младшего школьного возраста и роль учителя в общем музыкальном развитии их импровизационной деятельности.

Ключевые слова: импровизация, методы импровизации, импровизационные задания, основы импровизации, импровизационная деятельность.

Sharapova T. A. Activation of creative activity of junior pupils at music lessons.

The article examines teacher's methods and techniques of teaching to improve musical creativity of pupils by means of improvisation. Improvisation as a kind of activity at music lessons and its influence on the pupils' musical development at primary school are considered. The methodology of organization of musical improvisatory activity of primary school pupils has been grounded. The teacher's role in general musical development of junior pupils has been presented.

Key words: improvisation, improvisation basics, improvisation techniques, improvisation activities, improvisational tasks.

У музичній педагогіці все частіше порушуються питання про емоційну насиченість занять, інтенсифікацію процесу навчання. Емоційне сприймання невіддільне від переживання музичного образу, розвитку фантазії, образного мислення. Музика, радуючи i захоплюючи дітей, викликає в них відповідні почуття, спонукає до роздумів. «Музика $\epsilon$ насамперед однією з функцій свідомості, яка організовує життя та будує культуру», - писав Б. Асаф'єв [1, с. 37].

Підвищення ефективності та якості навчання й виховання в нашій країні вимагає, щоб учителі музики переходили від стереотипного, інтуїтивного підходів до науковообгрунтованого вибору оптимальних варіантів побудови навчально-виховного процесу.

Спостерігаючи за дітьми на уроках музики в школі, спілкуючись з учителями музики, можна зробити висновок, що організація навчального процесу вимагає нового підходу у формах, які забезпечують не пасивне сприйняття, а передбачає активну діяльність тих, хто навчається.

Розкриттю творчого потенціалу та музикальності дитини засобами музики присвячено багато педагогічних праць. Під музикальністю розуміють сукупність здібностей, необхідних для успішної музичної діяльності. Основна ознака музикальності- переживання музики як вираження певного змісту. Музичні переживання за своєю суттю $є$ емоційним переживанням, оскільки позаемоційним шляхом зміст музики осягнути не можна. Музикальність особливо виявляється в активній самостійній діяльності людини.

Уперше розроблення цієї проблеми почав Б. Асаф'єв. У 70-ті роки ХХ ст. його учнем Д. Кабалевським було введено в програму з музики новий елемент - імпровізацію. 
Ідею Б. Асаф’єва та Д. Кабалевського продовжили та розвинули Л. Горюнова та Л. Школяр. Педагогічну проблему імпровізації розкрив у своїй монографії В. Харькін, який виявив умови ефективності імпровізації в процесі діяльності вчителя музики.

Meта статmi - показати, що застосування методів і прийомів імпровізації на уроках музики є одним із ефективних засобів розвитку творчої активності школярів. Проілюструємо це на матеріалі відносної системи сольфеджування - релятивної системи.

Релятивна система недарма завоювала визнання у багатьох країнах світу як найзручніша для початкового масового вокального хорового навчання, стала основою музичного виховання. Вона проста й наочна, лад не подається дітям у вигляді готової схеми, а ніби виростає в міру вивчення все нових ступенів. Рухома тоніка дає змогу використовувати зручний діапазон, не «сидячи» довго у непридатному для можливостей дитячого голосу до-мажорі, який хоч-не-хоч мусиш використовувати у роботі за абсолютною системою. Не випадково протягом усієї нової історії реформатори музичного навчання наполегливо зверталися до відносної системи сольфеджування, намагаючись спростити, демократизувати, наблизити до мас музичне мистецтво. На сучасному етапі вона продовжує удосконалюватись завдяки практичним доробкам творчих учителів музики.

«Імпровізація» в перекладі 3 італійської та латинської мов означає несподіваний, раптовий, особливий вид художньої творчості, коли складання твору відбувається безпосередньо в процесі виконання. Мета імпровізації- розвинути музичний слух, творчі здібності та фантазію дітей.

У молодших школярів багата уява, вони люблять фантазувати й імпровізувати. Тому вчитель повинен вдало використовувати цю особливість дітей під час уроків музики.

Музично-творча діяльність учнів виявляється в різних видах імпровізації: вокальній, інструментальній, танцювальній; у різноманітних зображувальних рухах, що проводяться у формі ігор, вправ, мімічних сцен. Вона сприяє переходу від несвідомо-емоційного сприйняття засобів музичної виразності до теоретичного аналізу власних творів.

У навчанні молодших школярів доцільно використовувати такі види імпровізації: ритмо-мелодичні- у формі ритмічного та музичного діалогу, ритмодекламація тексту, ритмічні запитання й відповіді, складання мелодії на заданий ритм, складання мелодії на знайомі або власні тексти, добір ритмічного акомпанементу до знайомих пісень та музичних інструментальних творів.

Імпровізаційні завдання необхідно тісно пов'язувати із засвоєнням програмового матеріалу з хорового співу, музичної грамоти та слухання музики і варіювати на роках залежно від обсягу знань і умінь дітей. Складність творчих завдань зростає поступово. Такі завдання сприяють підвищенню активності учнів на уроці, допомагають краще усвідомити певні закономірності побудови мелодії, форми, значення окремих засобів музичної виразності, виконавських засобів, які підпорядковані розкриттю художнього образу музичного твору.

На початкових етапах застосування методу імпровізації від учнів можна вимагати тільки уміння продовжити мелодію у відповідному характері чи дати відповідь на поставлене ритмічне запитання без запису на нотному стані. До запису можна переходити лише тоді, коли діти добре засвоять поєднання четвертних і восьмих у різних ритмічних зворотах та набудуть навичок співу по вивчених ступенях, що пропонуються для мелодійної імпровізації.

Уводити елементи імпровізації доцільно якомога раніше, з перших уроків у першому класі - наприклад, почати урок не із звичайної переклички або перевірки музичних даних, а 3 
ритмічних малюнків імен і прізвищ дітей.

$\begin{array}{cccccccc}\text { I } & \text { I } & \Pi & \Pi & \text { I } & \text { I } & \Pi & \text { I } \\ \text { Tа- } & \text { ня } & \text { Гу- ца- } & \text { лен- ко } & \text { Вi- } & \text { тя } & \text { I - ва- } & \text { нов }\end{array}$

Можливі й інші варіанти завдань. Наприклад:

1. Додати до ритму вивчені ступені $3 \mathrm{O}$ - ВІ. Діти проспівають свої імена і прізвища імпровізаційно додаючи звуки.

2. Самостійно скласти музичне привітання. Діти створюють ритм, додають вивчені ступені, складають текст.

3. Попереднє завдання можна ускладнити, додаючи кількість тактів.

На початковому етапі ритмічного виховання застосовується такий вид роботи, як ритмодекламація тексту. Вона допомагає відтворювати нескладні ритмічні малюнки, усвідомити роль ритму для побудови й розвитку мелодії.

Спочатку слід давати дітям прості завдання та поступово ускладнювати їх, збільшуючи обсяг тактів та слів. Для створення ритмічних малюнків учні декламують окремі слова чи поспівки у відповідному ритмі, з логічним наголосом на тому чи тому складі: Дощик на- кра-па

Гon, zon, гу-my-my

Зва- ри каш- ку кру- ту.

Далі вчитель пропонує учням форму ритмічних запитань і відповідей, ритмічні діалоги. Учитель запитує, а хтось із учнів відповідає на основі вільної імпровізації.

Запитання:

Вidnовіді:

2 II I | II I || ?

2 II II | I I ||

2 I I | I II || ?

2 II I | I II ||

Задля ускладнення завдань учням пропонується форма музичних діалогів. Спочатку це двотактні запитання вчителя, які найчастіше закінчуються квінтою, а відповіді учнів мають тонічне завершення. Вести музичний діалог між собою учням значно важче - адже в запитанні вже міститься певний зразок (лад, метр, ритм) для відповіді. Тому розпочинати діалог повинен сам учитель, поступово залучаючи до участі найбільш обдарованих та ініціативних дітей, а до відповідей заохочуються сором'язливі й менш здібні учні.

Запитання:

2

2

$\begin{array}{ccc}\text { I I } & \text { IZ } \| & ? \\ \text { з в } & 3 & \\ \text { П П } & \text { I Z } \| & ? \\ \text { з з р р } & 3 & \end{array}$

Biдnовідi:

$\begin{array}{ccc}2 & \text { I I } \mid & \text { I Z } \| \\ & \text { з в } & \text { й } \\ 2 & \text { П П } \mid & \text { I Z } \| \\ & \text { з з в в } \mid & \text { й }\end{array}$

Діти відповідають на запитання, проспівуючи музичні ступені та показуючи їх ручні знаки. Кращий варіант відповіді бажано записати на дошці, а потім просольфеджувати його усім класом.

Однією із форм роботи, яка вимагає від учнів вільного володіння програмовим матеріалом із музичної грамоти і засобами виразного співу, є складання мелодій на знайомі або власні тексти. Для таких імпровізаційних завдань слід добирати нескладні віршовані тексти з виразним емоційно-образним змістом та чіткою ритмічною побудовою. 
У методиці вокальної імпровізації важлива підготовча робота: виразне читання тексту, орієнтація учнів на усвідомлення його змісту, визначення головної думки, переданої в назві твору чи в окремих реченнях, пояснення незрозумілих слів чи словосполучень, установлення зв'язку елементів музичної мови для передачі змісту даного твору.

3'ясувавши зміст і характер майбутньої мелодії, учитель пропонує дітям знайти відповідний ритмічний малюнок до вірша, потім скласти мелодію з використанням окремих звуків чи інтонаційних зворотів, які вони добре засвоїли під час співу ступенів та закріпили у слуховій уяві.

За потреби вчитель допомагає учням знайти ритмічний малюнок чи доцільну вокальну інтонацію, залучає учнів до висловлювання своїх суджень щодо відповідності тих чи тих інтонацій для відтворення змісту літературного тексту.

Можна ускладнити завдання у такий спосіб: запропонувати учням імпровізувати пісні на власні тексти. Бажано, щоб найкращий варіант мелодії учитель записав на дошці та проспівав його з учнями, спочатку називаючи ступені, потім зі словами. При виконанні таких пісень доречно, щоб діти вносили свої пропозиції щодо засобів виразного співу (характер звука, зміна динаміки тощо) відповідно до змісту вірша.

Наведемо приклади віршованих текстів, які можуть бути використані для вокальної імпровізації. Учням пропонується придумати інтонацію годинника або спів зозулі.

Тік -так, тік-так,

$\kappa y-\kappa y, \kappa y-\kappa y$

цокочу весь день отак.

чуєм зранку у ліску.

Доцільно продемонструвати, як на один і той самий текст створюється кілька різних варіантів ритму й мелодії. Можна складати ритмічні малюнки й мелодії до народних прислів'їв, приказок, скоромовок. Спочатку необхідно виконувати завдання усно, потім діти викладають паличками для рахунку ритмічний малюнок, відтворюють кружечками на нотному стані мелодію без ритму й тільки після такої підготовки починають записувати найпростіші приклади на нотному стані.

Відповідно до загального рівня розвитку учнів та їхньої підготовки завдання поступово ускладнюються. Учителю необхідно старанно готуватися до таких завдань, точно визначати мету кожного. Точніше кажучи, учень повинен «створювати» мелодію за допомогою вчителя, а сам бути впевненим, що це його особиста творчість.

Візьмемо такий простий текст:

Осінь листячком своїм

землю покриває.

Учитель виразно його читає, підкреслюючи ритмічні одиниці:

$\begin{array}{lllllll}\Pi \Pi & \Pi & \text { I } & \Pi \Pi & \text { I } & \text { I }\end{array}$

О-сінь лис-тяч- $\quad$ ком сво- $\quad$ їм $\quad$ зем-лю пок-ри- $\quad$ ва - $\epsilon$

Тепер учням неважко відтворити ритмічний малюнок цього тексту. Далі учням пропонується скласти нову пісню, проспівуючи ритмічні одиниці на двох знайомих звуках 30 і ВI. Отже, учням залишається тільки підставити до ритмічного малюнку ступені 30 і ВI. Змінюючи їх послідовність, можна отримати різні варіанти мелодії. Наступного разу вчитель може ускладнити й урізноманітнити завдання, запропонувавши дітям самостійно створити ритмічний малюнок на власноручно складений текст, збільшити кількість ступенів для мелодійного викладу (3О, ВІ, РА; ВІ, РА, ЙО).

Імпровізація $€$ ефективним засобом розвитку гармонічного слуху. Доцільно іiі 
пов'язувати з малюванням. Звісно, на уроці музики можна дозволити учням лише кілька разів за семестр зайнятися малюванням ілюстрацій до прослуханої музики або власної імпровізаційної мелодії. Але задаючи додому завдання створити мелодію на короткий віршик, пропонуємо виконати й малюнок до цієї пісні. Такі завдання діти виконують залюбки.

У подальшій роботі вчитель пропонує учням поспівки, які не мають закінчення чи початку.

Цікавою формою роботи, яка вимагає концентрації уваги учнів, сприяє розвитку їхньої творчої уяви і відчуття форми, є складання варіацій. Наприклад, учитель записує на дошці певний ритмічний малюнок, а учні складають його варіанти (варіації на певних ступенях, ритмічні варіанти на незмінних ступенях, мелодійні варіації при незмінному ритмі, варіювання мелодичних закінчень).

Такі завдання готують дітей до психофізіологічного сприйняття ритмічного боку мелодії, сильної і слабкої частки. У дитини 6-7-річного віку зорове сприйняття набагато гостріше, ніж слухове. Тому при вивченні музично-теоретичного матеріалу і виробленні музичного слуху з перших же днів необхідно приділяти увагу зорово-слуховому сприйняттю. Чим яскравіше зорове уявлення, тим успішніше і глибше слухове засвоєння матеріалу.

Задля концентрації уваги, активізації внутрішнього слуху й загострення відчуття ритму корисно проводити з учнями спеціальні вправи. Учитель записує на дошці ритмічний малюнок знайомої дітям пісні, в якій переставлені місцями такти, а вони повинні виправити «помилки».

3 набуттям нових знань і навичок розширюються можливості пов'язувати творчі завдання з нотною грамотою. У спробах власної творчості закріплюється такий теоретичний матеріал, як поняття про музичну форму, розмір, тональність.

Творчі вправи вносять в урок багато цікавого, пожвавлюють його. Діти з інтересом сприймають імпровізацію маленьких сценок у ролях, співання імпровізацій на тему загальновідомих простих казок, скажімо, таких, як «Колобок», «Ріпка», «Рукавичка». Ще цікавіше дітям, коли сюжет казки також складений ними.

3 перших кроків доцільно привчати учнів слухати, оцінювати, коментувати власні твори і твори своїх товаришів, робити висновки, зауваження. Бажано в ігровій формі проводити виставлення учнями оцінок за власні твори й твори однокласників з наступною мотивацією - чому сподобався саме цей твір. Учителю необхідно стимулювати самостійні пошуки учнів, що краще за будь-які види занять допоможуть відчути виразність музики. Не слід карати дітей за невиконане творче завдання, краще заохотити, похвалити хоч би за невеличкі успіхи.

Отже, щоб творчі прояви дітей на заняттях мали цілеспрямований, активний та емоційний характер, педагогу необхідно:

1. Добирати такий музичний матеріал, який може бути основою для формування конкретних творчих навичок і в той же час відповідатиме дидактичним вимогам.

2. Застосовувати прийоми, методи і форми роботи, які сприяють створенню на уроці атмосфери творчої активності, зацікавленості, невимушеності.

3. Вибирати прийоми показу зразків творчості в різноманітних видах музичної діяльності учнів.

4. Імпровізувати різними способами.

5. Розробляти і ставити серії творчих завдань.

6. Встановлювати найбільш раціональну взаємодію видів діяльності на кожному 
уроці відповідно до теми.

Отже, розвиток творчих здібностей дитини на уроці музики залежить від ініціативи та майстерності вчителя в доборі музичного матеріалу до уроку та методів роботи 3 ним. Застосування прийомів імпровізації на уроках музики $є$ одним із ефективних засобів розвитку творчої активності школярів.

\section{Література}

1. Ветлугіна Н. О. Музичний розвиток дитини / Н. О. Ветлугіна. - Київ : Муз. Україна, 1978. - 256 с. 2. Ростовський О.Я. Педагогіка музичного сприймання / О. Я. Ростовський. - Київ : ІЗМН, 1997. - 248 с. З. Асафьев В. В. Избранные статьи о музыкальном просвещении и образовании. - [2-е изд.]. / В. В. Асафьев. - Ленинград : Музыка, 1973. - 144 с. 4. Выготский Л. С. Воображение и творчество в детском возрасте: Психологический почерк. - [3-е изд.]. / Л. С. Выготский. - Москва : Просвещение, 1991. $93 \mathrm{c}$.

Любов Шиачук

\section{ФОРМУВАННЯ ТВОРЧИХ ЗДІБНОСТЕЙ МОЛОДШИХ ШКОЛЯРІВ У НАВЧАЛЬНО-ВИХОВНОМУ ПРОЦЕСІ ПОЧАТКОВОЇ ШКОЛИ}

Шпачук Л. Р. Формування творчих здібностей молодших школярів у навчальновиховному процесі початкової школи.

У статті, спираючись на сучасні досягнення педагогічної науки та практики, визначаються найбільш дієві дидактичні умови як засіб формування творчих здібностей молодших школярів, що з успіхом можуть бути використані на уроках рідної мови у початковій школі.

Ключові слова: творчість, креативні освітні технології, інтеграція, інтерактивне й ігрове навчання.

Шпачук Л. Р. Формирование творческих способностей младших школьников в учебно-воспитательном процессе начальной школы.

В статье на основе анализа современных достижений педагогической науки и практики определяются наиболее действенные дидактические условия как средства формирования творческих способностей младших школьников, которые с успехом могут быть использованы на уроках родного языка в начальной школе.

Ключевые слова: творчество, креативные образовательные технологии, интеграция, интерактивное и игровое обучение.

Shpachuk L. R. Formation of creative abilities of junior pupils in the educational process at primary school.

In the article based on the analysis of current achievements of pedagogical science and practice the most effective didactic conditions as means of formation of creative abilities of junior pupils are determined. These conditions should be used at the native language lessons at a primary school. It also focuses the attention on the effective methods, ways and forms of teaching.

Key words: creativity, creative educational technology, integration, interactive and game training, basic research methods of education. 